\title{
Assessment of the financial efficiency of the educational program implementation, considering the fulfillment of target indicators imposed on average salary and the student/teacher ratio
}

\author{
Sergey S. Vikharev \\ Volgograd State University, \\ Institute of Mathematics and Information Technologies \\ Volgograd, Russia \\ s.viharev@volsu.ru
}

\author{
Sergey A. Korolkov \\ Volgograd State University, \\ Institute of Mathematics and Information Technologies \\ Volgograd, Russia \\ sergei.korolkov@volsu.ru
}

\author{
Irina M. Samokhina \\ Volgograd State University, \\ Institute of Mathematics and Information Technologies \\ Volgograd, Russia \\ samokhina-im@volsu.ru
}

\begin{abstract}
The purpose of the study is to develop methods and algorithms of financial analysis and management of educational process in a university. The paper presents a financial and mathematical model for assessing the profitability of any educational program implemented in the university. The model is based on the main goals of the university, which are to achieve the basic performance targets and the fulfillment of the government task. The proposed methodology is innovative and represents a natural development of the method of normative per capita financing of university educational activity.
\end{abstract}

Keywords - educational program, profitability, financial efficiency of educational process, model of university management

\section{INTRODUCTION}

One of the goals in the educational institutions management is the transition from the management of structural units to the management of educational programs. The relevance of this issue is determined by many factors: the development and improvement of educational technologies, introduction of modern information technologies in educational process, significant change in the regulatory and legal framework, which regulates the sphere of education in Russia. Among the latter, it is necessary to note the transition to the normative per capita order of financing the educational institutions in accordance with the implementation of the government task. In this regard, it is important to develop new, adequate to the situation methods for allocation of financial and other resources in the process of educational programs management and mechanisms for monitoring the effectiveness of implemented innovations.

\section{MATERIALS AND METHODS (MODEL)}

The researches in this field conducted in recent decades are mostly devoted to the problems of the economic and legal nature of educational services, financial and budgetary aspects of educational institutions activities, and analysis of foreign experience [1], [2]. At the same time, the problems of effective organization of educational process, profitability of specialists training, optimality of using financial, material and human resources are practically not studied. It should be noted that the higher educational institution is not a commercial organization, and it is most probably incorrect to demand profit maximization from it. It would be more prudent to consider as a goal the improvement of the efficiency and effectiveness of the resources use. At the moment, most algorithms for financial resources allocation, formation of staff schedule and wages fund are extremely demanding and are based on the indicators of the total workload of teaching staff [3]. In papers [4], [5], [6], a new algorithm for the formation of the wages fund of a university's teaching staff was proposed. The algorithm assumes financing in proportion to the share of each department in the implementation of educational process of each educational program. The share of each department in the implementation of educational process of the specific educational program of a certain year of study is formed on the basis of this educational program curriculum of the current academic year according to the "labor intensity 
in mastering the discipline" indicator. The value of the indicator is expressed in credits (in contrast to the demanding methods, where the share of the department is determined on the basis of the volume of the academic workload expressed in academic hours of the teaching staff workload). The methodology proposed by the authors provides an opportunity to determine the optimal variants of the teaching staff structure, which can be accepted in terms of the system of restrictions imposed by the conditions of the academic workload. At the same time, it ensures the formation of a management strategy that allows to achieve improvement of certain indicators by increasing their "weights". Thus, according to the results of implementation of this method in Volgograd State University (VolSU), the following results were achieved [7].

TABLE I. THE RATIO OF THE GIVEN CONTINGENT OF STUDENTS OF AN EDUCATIONAL INSTITUTION TO THE TOTAL NUMBER OF TEACHING STAFF (WITHOUT EXTERNAL PART-TIME WORKERS AND STAFF WORKING UNDER CIVIL LAW CONTRACTS)

\begin{tabular}{|c|c|c|c|c|}
\hline & 2013 & 2014 & 2015 & $\begin{array}{c}\text { Dynamics } \\
(2015 / 2013, \%)\end{array}$ \\
\hline $\begin{array}{l}\text { Target in } \\
\text { accordance } \\
\text { with the Road } \\
\text { map }\end{array}$ & 10.2 & 10.5 & 10.7 & $104.9 \%$ \\
\hline VolSU & 10.18 & 11.05 & 11.84 & $116.33 \%$ \\
\hline HEI $x_{1}$ & 8.86 & 8.67 & 8.62 & $97.31 \%$ \\
\hline HEI $x_{2}$ & 7.9 & 8.06 & 8.05 & $101.9 \%$ \\
\hline $\mathrm{HEI}_{3}$ & 9.5 & 9.59 & 9.34 & $98.37 \%$ \\
\hline $\mathrm{HEI} \mathrm{x}_{4}$ & 9.89 & 10.47 & 10.8 & $109.29 \%$ \\
\hline HEI $x_{5}$ & 10.8 & 10.72 & 10.66 & $98.77 \%$ \\
\hline HEI $_{6}$ & 9.71 & 9.87 & 9.8 & $100.89 \%$ \\
\hline
\end{tabular}

The formation of a new model of financial support to the activities of educational institutions on the basis of normative per capita financing for the implementation of the government task requires the development of new calculation methods of such fundamental values as "prime cost", "profitability" and "efficiency". The authors of the article [4] proposed an estimation mechanism for prime cost of the educational program curriculum components and the effectiveness of the educational process organization (normative and actual). The idea was to compare the actual and normative expenses for financing the academic staff schedule within the framework of the implementation of a specific educational program with the actual contribution of this educational program to the formation of the wages fund of the teaching staff (actual and normative efficiency of the educational program). It should be noted that the normative efficiency shows how effectively (in the financial sense) the educational program curriculum have been drawn up in compliance with the existing students contingent of the educational program, while the "actual efficiency" represents the degree of optimality of the actual staff schedule with the existing curriculum and the existing students contingent of the educational program. This paper is devoted to assessing the practical application of these methods in Volgograd State University and developing additional indicators of profitability and effectiveness of educational programs.

According to [4], the actual financial efficiency of educational process organization of the considered educational program is calculated by the formula:

$$
\ni \Phi_{\text {ОП }}=\frac{K_{-} \text {студ } \times \text { Норм_финанс_ОП }}{\sum_{\partial и с ц} C \Phi_{-} \text {диси }} \times 100 \%
$$

where Hорм_финанс_ОП - the normative part of educational program financing (in rubles per one student), allocated by the university for the teaching staff salary (directed to the wages fund of teaching staff);

$K \_c m y \partial$ - the actual number of students contingent of a particular year of the considered educational program;

СФ_дисц - the actual prime cost of the educational program curriculum components, which is defined as follows:

$$
C \Phi_{-} \partial u c y=\sum_{A_{-} \partial u c u} \frac{O_{i} \cdot T_{i}^{\partial u c u} \cdot k_{i}^{\partial u c y}}{N_{i}},
$$

where $A \_\partial u c u$ - the number of all teachers $\left\{Y_{i}\right\}$ providing the teaching workload for the considered discipline of the considered educational program (of the considered year of study);

$O_{i}$ - the standard amount of salary (RUB) per 1 rate of teacher position $Y_{i}$;

$T_{i}^{\text {ducy }}$ - the number of hours (per year) in the individual workload of a teacher $Y_{i}$ in this discipline;

$N_{i}$ - number of hours per 1 rate of teacher $Y_{i}$;

$k_{i}^{\partial u c u}$

- the percentage of students of the considered cational program in the total flow of students in case the corresponding discipline workload is provided in the flow of several educational programs (otherwise, the index amounts to $\left.k_{i}^{\text {ducu }}=1\right)$.

In turn, the normative financial efficiency of the educational process organization is calculated by the formula

$$
\ni H_{\text {OП }}=\frac{K_{-} \text {студ } \times \text { Норм_финанс_ОП }}{\sum_{\text {диси }} 3 H_{-} \text {оиси }} \times 100 \%
$$

where 3Н_дисц - the normative expenses for the educational process organization of the curriculum discipline, which is calculated as follows: 


$$
\begin{aligned}
& \text { 3H_диси }=\frac{O_{-} \partial \cdot T_{x}^{\text {ducu }} \cdot k_{x}^{\text {ducu }}}{N_{c}}+\frac{O_{-} c \cdot T_{y}^{\partial u c u} \cdot k_{y}^{\partial u c y}}{N_{c}}+ \\
& +\frac{O_{-} a \cdot T_{z}^{\partial u c u} \cdot k_{z}^{\partial u c u}}{N_{c}}
\end{aligned}
$$

- for disciplines (modules) of block 1 of educational program and

$$
3 H_{-} \partial u c u=\frac{O_{-} n \cdot T_{\text {mup }}^{\text {ducy }}}{N_{c}}
$$

- for practical trainings and final state examination of blocks 2 and 3 of educational program.

Here, as before, $O \_n-$ the normative fixed official salary of a professor (Doctor of Science) set in the university;

$O \_\partial-$ the normative fixed official salary of an associate professor (Candidate of Science) set in the university;

$O \_c-$ the normative fixed official salary of a senior teacher (without a degree) set in the university;

$O \_a-$ the normative fixed official salary of an assistant (without a degree) set in the university;

$T_{x}^{\text {ducy }}\left(T_{y}^{\text {ducu }}, T_{z}^{\text {ducy }}\right.$, respectively) - the number of hours (per year) in individual workloads of teachers required to provide lectures (seminars, laboratory works, resp.) for the discipline under consideration;

$k_{x}^{\partial u c y}\left(k_{y}^{\partial u c y}, k_{z}^{\partial u c y}\right.$, resp.) - percentage of students of the considered educational program in general lecture (seminary, laboratory, resp.) stream in case the lecture (seminary, laboratory, resp.) discipline workload is provided in the stream of several educational programs (otherwise, the index amounts to $k_{x}^{\text {ducu }}=1$ );

$T_{\text {нир }}^{\text {дису }}$ - the number of hours allocated for the workload implementation of the training blocks B2, B3 of the considered educational program;

$N_{c}$ - the amount of an average individual workload of the teaching staff per 1 rate in university.

It is easy to notice that comparing different educational programs according to $Э H_{о \Pi}$ index, it is possible to evaluate the financial efficiency of curricula; when comparing the different educational programs according to the $Э Ф$ оп index, it is possible to draw conclusions about the financial efficiency of the staff schedule, which provides the workload of the educational program under the existing curriculum.

\section{RESULTS AND DISCUSSION}

At the moment on the basis of accumulated experience it is possible to assess the practical result of applying these methods on the example of educational programs of Volgograd State University. Thus, in 2017 the following results were obtained.
TABLE II. THE EFFICIENCY OF THE EDUCATIONAL PROCESS ORGANIZATION FOR SOME EDUCATIONAL PROGRAMS OF VOLSU

\begin{tabular}{|c|c|c|c|}
\hline $\begin{array}{c}\text { Program of } \\
\text { study }\end{array}$ & $\begin{array}{c}\text { Students } \\
\text { contingent }\end{array}$ & $\begin{array}{c}\text { Actual financial } \\
\text { efficiency }\end{array}$ & $\begin{array}{c}\text { Normative financial } \\
\text { efficiency }\end{array}$ \\
\hline Program 1 & 241 & 1.12 & 1.75 \\
\hline Program 2 & 121 & 1.6 & 1.86 \\
\hline Program 3 & 29 & 1.25 & 1.23 \\
\hline Program 4 & 30 & 1.42 & 1.42 \\
\hline Program 5 & 562 & 2.02 & 2.65 \\
\hline Program 6 & 88 & 1.62 & 1.98 \\
\hline
\end{tabular}

According to this information, it is possible to notice the educational programs, which showed mediocre effectiveness despite the large contingent of students. It may be caused by non-optimal organization of the educational process or an inadequate approach to the educational program curriculum development. In addition, this information allows to notice those educational programs, the actual effectiveness of which is equal to or even worse than the normative one. This refers to a conclusion that the staff schedule of departments involved in the implementation of these educational programs is nonoptimal.

It should be noted that the proposed methods essentially depend on the size of the normative part of the educational program financing (in rubles per student) allocated by the university to the wages fund of teaching staff in order to finance the basic part of wages, which includes salary and incentive payments. In this regard, there is an issue to determine the effectiveness of educational programs with regard to the entire amount of the teaching staff wages, which is being considered during calculation of the target indicators specified in the Road map "Changes in social sectors aimed at improving the efficiency of education and science" [8]. According to this document, the ratio of average salary of the teaching staff of educational institutions of higher education to the average salary in the corresponding region should amount to $200 \%$ in 2018 . In addition, according to the same document, in 2018 the number of students per 1 teacher should amount to 12 people. It is evident that the fulfillment of these requirements of the Road map entails the necessity to calculate the standard of deductions to the teaching staff wages fund from 1 student of the given contingent according to the following formula:

$$
S_{N}=\frac{\left(S_{C p}-S_{H}-S_{\Gamma T X X}\right) * k * 12}{K} .
$$

Here, $S_{N}$ - the normative part of the educational program financing (in rubles per student), allocated by the university to the wages fund of the teaching staff;

$S_{c p}$ - the target index of the average salary for 1 rate of the teaching staff per month according to the Road map;

$S_{\boldsymbol{H}}$ - the average monthly rate of the teaching staff salary for performing work within the framework of financial support for targeted projects of Russian research funds (RFBR, RSF and others); 
$S_{\Gamma \Pi x}$ - the average monthly rate of salary of the teaching staff working under civil law contracts;

$\boldsymbol{k}$ - a correction factor equal to the ratio of the average number of staff to the number of rates of the teaching staff positions;

$\mathbf{K}$ - the target indicator representing the ratio of the number of students of the given contingent for 1 teaching staff rate in accordance with the Road map.

With reference to Volgograd State University, it should be noted that the $S_{N}$ index calculated according to the formula (1) in 2018 should amount to approx. 35,500 rubles (taking into account the known for VolSU values of $\boldsymbol{S}_{\boldsymbol{n}}=2.460$ rubles per month for 1 teaching staff rate, $S_{c l c}=550$ rubles per month for 1 teaching staff rate, $\mathrm{k}=0.78, \mathrm{~K}=12$ ).

In addition, according to the recommendation of the Ministry of Education and Science of the Russian Federation, the basic part of the teaching staff salary should be not less than $70 \%$ of its total size. This allows us to calculate the profitability of each educational program using the following formula:

$$
r=\frac{F_{\Pi \Pi C}}{f_{\text {фaкm }}}
$$

where $F_{\Pi \Pi C}$ the teaching staff wages fund allocated by the educational institution for one year for the educational program implementation, which is calculated as the product of the normative part of the deductions from one student to the wages fund of teaching staff and the given contingent for the corresponding educational program;

$f_{\text {факm }}$ - the actual expenses of educational institution for the payment of the basic part of the teaching staff salary for the corresponding educational program.

The indicator $f_{\text {paкm }}$ is calculated according to the formula

$$
f_{\text {фaжm }}=12 * S_{N} * 70 \% * \frac{N_{O \Pi}}{N_{c p}}
$$

where $N_{\text {OI }}$ - the teachers workload of the given educational program in the considered academic year, $N_{c p}$ the average workload per 1 rate of the university teaching staff.

The remaining $30 \%$ of the wages fund, which are not dedicated to the payment of the basic part of salary, are used for incentive payments to employees for the fulfillment of effective contracts conditions and the achievement of target indicators in scientific work.

As a result of calculations of profitability of several educational programs of VolSU in 2017/2018 academic year, the following results were obtained according to the formula (2).
TABLE III. PROFITABILITY OF THE EDUCATIONAL PROGRAMS OF VOLSU IN 2017/2018 ACADEMIC YEAR

\begin{tabular}{|l|c|}
\hline \multicolumn{1}{|c|}{ Program of study (educational program) } & Profitability \\
\hline 45.00 .00 Program 1 & 0.95 \\
\hline 38.00 .00 Program 2 & 0.83 \\
\hline 39.00 .00 Program 3 & 1.04 \\
\hline 09.00 .00 Program 4 & 1.2 \\
\hline 10.00.00 Program 5 & 1.3 \\
\hline 05.00 .00 Program 6 & 1.43 \\
\hline 02.00 .00 Program 7 & 1.58 \\
\hline 40.00 .00 Program 8 & 4.13 \\
\hline Average for VolSU & $\mathbf{1 . 4 3}$ \\
\hline
\end{tabular}

It should be noted that these calculations were performed without considering the possible optimization of the educational program organization at the level of departments and institutes (for example, by combining the contingent of close educational programs into lecture streams on the same disciplines of the curriculum), which can significantly improve the profitability index.

According to the information above on the basis of this index it is possible to divide the educational programs into three groups: unprofitable (profitability index less than 1.0), conditionally profitable (profitability index from 1.0 to 1.43 ) and profitable (profitability index more than 1.43).

Unprofitable educational programs without additional optimization of the educational process or attraction of funds, for example, from extrabudgetary sources of the institute, will not be able to provide funding of the teaching staff schedule involved in the educational program implementation (at the established normative part of the deductions from one student to the wages fund of teaching staff), for conditionally profitable educational programs - the share of the basic part in the salary of teaching staff involved in the educational program implementation will be from $70 \%$ to $100 \%$.

It should be noted that the proposed method of calculating the profitability of educational programs takes into account all modern normative acts regulating the sphere of formation of teaching staff wages funds and allows to compare the effectiveness of the educational process organization between different educational programs.

\section{CONCLUSION}

The article considers the model for assessment the efficiency of educational programs implementation in higher education institutions subject to fulfillment the requirements of the Road map "Changes in social sectors aimed at improving the efficiency of education and science". Due to this methodology, the management of the educational institution receives an additional source of operational information for the timely assessment of the effectiveness of the educational process and the management decision making. This methodology can be extended to other universities in the region. 
The introduction of this methodology in VolSU contributed to the following results:

1. The attention to the economic rationale of the educational process organization has significantly increased among the heads of the structural units that provide such activity (heads of departments, directors of institutes, heads of educational and methodical departments, etc.).

2. Heads of departments gained an opportunity to adequately and reasonably plan staff schedules for the medium-term period (3-5 years).

3. The main parameters for forecasting the financial and economic results of the curriculum changes, opening new or closing existing profiles and programs of study, as well as the dynamics of the student contingent were determined.

4. The management of the university significantly reduced labor and time costs for the formation of structure of the university teaching staff as this aspect almost entirely became the responsibility of heads of departments. In fact, the departments became the centers of financial responsibility (at least in the issue of allocation to the teaching staff wages fund).

5. Economic levers for stimulating the implementation of the Road map "Changes in social sectors aimed at improving the efficiency of education and science" [8] have been formed.

\section{Acknowledgment}

The research was undertaken with financial support of the Russian Foundation for Basic Research (RFBR) and the Administration of Volgograd region, project "Financial and mathematical models and algorithms of budgeting of structural subdivisions of educational institutions" No. 17-12-34015.

\section{References}

[1] M.A. Borovskaya, M.A. Masych, I.K. Shevchenko, "The effective contract in the system of stimulation of academic staff " [Effektivnyi kontrakt $\mathrm{V}$ sisteme stimulirovaniya nauchno-pedagogicheskikh rabotnikov], Higher education in Russia [Vysshee obrazovanie v Rossii], 2013, Vol. 5, pp. 13-20.

[2] T.V. Fedosova, M.A. Borovskaya, M.A. Masych, M.V. Panichkina, "Financial security of the organizations of proffessional education and practice of definition of standard costs" [Finansovoe obespechenie organizatsii professional'nogo obrazovaniya i praktika opredeleniya normativnykh zatrat], Fundamental researches [Fundamental'nye issledovaniya], 2014, Vol. 12 (1), pp. 169-173.

[3] A.V. Dorzhdeev, N.A. Kizatova, A.G. Losev, N.V. Loseva, "A payroll generation model in relation to academic and teaching staff of higher educational institutions" [Finansovo-matematicheskaya model' formirovaniya fonda oplaty truda prepodavatelei SPO], Science Journal of VolSU. Global Economic System [Vestnik Volgogradskogo gosudarstvennogo universiteta. Seriya 3: Ekonomika. Ekologiya], 2015, Vol. 4 (33), pp. 227-234.

[4] S.A. Korolkov, A.G. Losev, I.M. Reshetnikova, V.V. Tarakanov, "Budgeting model of structural units based on normative per capita funding", European researcher, 2014, Vol. 3-1(70), pp. 498-508.

[5] S.A. Korolkov, I.M. Reshetnikova, V.V. Tarakanov, "The model of financial calculations in the distribution of the wage fund of the teaching staff in case of thr network form of educational programs implementation" [Model' provedeniya finansovykh raschetov pri raspredelenii fondov oplaty truda professorsko-prepodavatel'skogo sostava v sluchae setevoi realizatsii obrazovatel'nykh programm], Science Journal of VolSU. Global Economic System [Vestnik Volgogradskogo gosudarstvennogo universiteta. Seriya 3: Ekonomika. Ekologiya], 2014, Vol. 5 (28), pp. 99-107.

[6] S.A. Korolkov, A.G. Losev, I.M. Reshetnikova, "The model of optimal planning for the department regular staffing" [Model' optimal'nogo planirovaniya shtata PPS kafedr], Science Journal of VolSU. Global Economic System [Vestnik Volgogradskogo gosudarstvennogo universiteta. Seriya 3: Ekonomika. Ekologiya], 2013, Vol. 1 (22), pp. 149-154.

[7] S.A. Korolkov, A.G. Losev, V.V. Tarakanov, "Education programs management by education and finance plans implementation" [Upravlenie obrazovatel'nymi programmami cherez vnedrenie uchebnofinansovykh planov], University Management: Practice and Analysis [Universitetskoe upravlenie: praktika i analiz], 2016, Vol. 104 (4), pp. 49-55.

[8] The Government Of The Russian Federation, 2014, April 30, № 722-p [Rasporyazhenie Pravitel'stva Rossiiskoi Federatsii ot 30 aprelya 2014 g. № 722-r], Russian newspaper [Rossiiskaya gazeta], 2014, May 8. 